\title{
PENERAPAN PENGANGGARAN BERBASIS KINERJA DAN REFORMASI BIROKRASI DI INDONESIA
}

\author{
Ayu Okta Rezariski \\ Magister Perencanaan Ekonomi dan Kebijakan Pembangunan, Fakultas Ekonomi, \\ Universitas Indonesia \\ Email: ayuoktareza@gmail.com
}

\begin{tabular}{l}
\hline \multicolumn{1}{c}{ Artikel info } \\
\hline Artikel history: \\
Diterima : 06 November \\
2020 \\
Diterima dalam bentuk \\
revisi: 10 November 2020 \\
Diterima dalam bentuk \\
revisi: 19 November 2020
\end{tabular}

Keywords:

Performance-Based

Budgeting; Bureaucratic Reform.
Abstract: The aim of this research is Bureaucratic Reform (RB) which describes the measurement of organizationalperformance at ministries and institutions, Performance-Based Budgeting $(P B B)$, represented by indicators of Budget Absorption (P), Output Achievement $(P K)$ and Efficiency $(E)$ which are the focus of research and use 2 control variables consisting of the Budget Ceiling / Budget Allocation and the Number of State Civil Servants (ASN). This research method uses data on the achievements of the Bureaucratic Reform (RB) of Ministries and Institutions using the Bureaucratic Reform index approach derived from the assessment of the Ministry of Agriculture $R B$ from 2014 to 2018 Based on data for the 2014-2018 period, the results of this fixed effect panel estimate indicate that there is a direct relationship between performance-based budgeting and bureaucratic reform inIndonesia. Ministries or institutions with increased output / output index values, high absorption, low number of ASN, and the historical context of budgeting efficiency, also tend to experience an increase in the Bureaucratic Reform Index (RB).

Abstrak: Tujuannya Penelitian ini Reformasi Birokrasi (RB) yang menggambarkan pengukuran kinerja organisasi pada kementerian dan lembaga, Penganggaran Berbasis Kinerja (PBK), diwakili oleh indikator Penyerapan Anggaran (P), Pencapaian Keluaran (PK) dan Efisiensi (E) yang menjadi fokus penelitian dan menggunakan 2 variabel kontrol yang terdiri dari Pagu Anggaran/ Alokasi Anggaran dan Jumlah Aparatur Sipil Negara (ASN). Metode Penelitian ini menggunakan data capaian Reformasi Birokrasi (RB) Kementerian dan Lembaga menggunakan pendekatan indeks Reformasi Birokrasi yang berasal dari penilaian Kemenpan RB dari tahun 2014 sampai 2018. Berdasarkan data periode 2014- 2018, hasil dari estimasi panel fixed effect ini menunjukkan bahwa adanya hubungan langsung penganggaran berbasis kinerja terhadap Reformasi Birokrasi di Indonesia. Kementerianatau Lembaga dengan nilai indeks keluaran/output yang 
meningkat, penyerapan yang tinggi, jumlah ASN yang rendah, serta konteks historis efisiensi penganggaran, cenderung juga mengalami peningkatan Indeks Reformasi Birokrasi (RB).

\section{Koresponden author: Ayu Okta Rezariski}

Email: ayuoktareza@gmail.com

artikel dengan akses terbuka dibawah lisensi

\section{Pendahuluan}

Reformasi Birokrasi (RB) ditetapkan oleh Pemerintah Republik Indonesia sebagai prioritas nasional yang terdapat pada agenda pembangunan pemerintah dalam mewujudkan perbaikan tata kelola pemerintahan. Berdasarkan hasil survey PERC (2009) Indonesia dinobatkan sebagai negara terkorup di Asia Pasifik dijadikan sebagai dasar pemerintah menetapkan RB sebagai prioritas nasional. Demikian pula hasil survey World Bank tahun 2009 melalui indeks efektifitas pemerintahan Indonesia menempati posisi keenam dibawah Philipina.

Pengukuran Indeks Efektivitas Pemerintahan yang dilakukan oleh World Bank melalui indikator persepsi kualitas pelayanan publik, kredibilitas dan komitmen ASN terhadap kebijakan, kualitas Aparatur Sipil Negara (ASN) serta indepedensi ASN terhadap tekanan politik menggambarkan kurang efektifnya kemampuan Pemerintah dalam pengambilan kebijakan serta kurang optimalnya penyediaan barang publik. Begitu pula dengan hasil survey daya saing global yang menempatkan Indonesia pada peringkat 54 (2009). Ditinjau dari hasilhasil survey tersebut Indonesia mengalami kendala utama yakni inefisiensi dalam birokrasi pemerintahnya serta kurangnya dukungan infrastruktur dan juga korupsi yang masih merajalela di sektor publiknya (Taufiq, 2014).

Pemerintah menerbitkan beberapa paket kebijakan reformasi birokrasi dalam rangka mewujudkan birokrasi yang bersih, bebas dari korupsi, kolusi, nepotisme dan juga menghasilkan pelayanan publik yang berkualitas, diantaranya dengan mengeluarkan Perpres No.81 tahun 2010 tentang Grand Design Reformasi Birokrasi (Presiden Republik Indonesia, n.d.). Paket kebijakan ini merupakan bentuk dari keseriusan pemerintah Indonesia dalam menjadikan RB sebagai prioritas kebijakan pemerintah. Kebijakan Reformasi Birokrasi diharapkan dapat menjadi kebijakan yang mendorong birokrasi menuju ke arah yang lebih baik. Harus kita cermati bersama bahwa reformasi birokrasi merupakan indikator penilaian penting guna mendukung peningkatan kesejahteraan masyarakat dan pembangunan ekonomi dimana proses bisnis dalam menjalankan sektor publik dikendalikan sepenuhnya oleh para birokrat.

Ketika berbicara terkait reformasi birokrasi yang menjadi tantangan utama dalam melakukan penelitian ini adalah mendefinisikan dan mengukur birokrasi yang telah diimplementasikan serta menentukan model dan metodologi yang tepat untuk mengestimasi implementasi birokrasi yang telah dilakukan serta merancang skenario untuk mengestimasi efek dari peningkatan reformasi birokrasi terhadap tata kelola pemerintahan yang baik. Untuk mengetahui variabel yang menjadi ukuran dalam menggambarkan tata kelola pemerintahan 
yang baik, diketahui Kementerian Keuangan mengenalkan konsep penganggaran berbasis kinerja dalam sistem pengelolaan penganggaran yang modern di Indonesia, variabel yang digunakan dalam penganggaran berbasis kinerja meliputi pengukuran kinerja anggaran melalui aspek input, output, serta outcome yang akan dicapai. Perkembangan konsep penganggaran berbasis kinerja pada pemerintah pusat di Indonesia sesungguhnya didasari oleh teori penetapan tujuan yang diperkenalkan oleh (Locke \& Bryan, 1969). Teori ini berpendapat bahwa untuk mencapai kinerja maksimum, diperlukan formula yang jelas antara target dan output indikator kinerja. Gagasan tersebut meyakini bahwa apabila tujuan telah didefinisikan dengan jelas, maka akan menghasilkan kinerja yang baik, dengan asumsi bahwa terdapat dukungan dalam pencapaian tujuan yang ditetapkan (Basri, 2013; Locke, 1975). Namun dalam praktiknya pengimplementasian penganggaran berbasis kinerja yang telah dilaksanakan oleh pemerintah pusat di Indonesia dalam rangka mempertahankan stabilitas keuangan belum mampu membawa Indonesia dalam mewujudkan pemerintahan yang efektif dan efisen.

Dasar hukum dalam pengimplementasian penganggaran berbasis kinerja yang menjadi acuan pemerintah Indonesia terdapat pada Undang-Undang No. 17 Tahun 2003 tentang Keuangan Negara (Pemerintah Republik Indonesia, 2003). Pada Undang-undang tersebut diamanatkan bahwa pengelolaan penganggaran yang diimplementasikan di Indonesiamenganut pendekatan sistem penganggaran yang didasari oleh prestasi kerja dan kinerjasetiap individu. Pada undang-undang tersebut terfokus pada upaya memperbaiki proses penganggaran di Indonesia dengan penerapan anggaran yang didasari oleh perencanaan kinerja yang menitikberatkan pada penyusunan anggaran berdasarkan kinerja yang akan dicapai pada setiap Kementerian dan Lembaga.

Salah satu aspek yang yang ditekankan pada peraturan dalam undang-undang tersebut juga bahwa penentuan kebijakan umum anggaran harus diikuti dengan formulasi pencapaian target kinerja yang terukur. Tujuannya agar informasi yang tertuang pada RKA (Rencana Kerja Anggaran) Kementerian/ Lembaga akan dijadikan sebagai dasar dalam realisasi anggaranIndonesia berhasil mencapai lonjakan yang cukup siginifikan dalam skor efektivitas pemerintahan selama periode pimpinan Presiden Joko Widodo dan Wapres Jusuf Kalla. Dua faktor pendorong tersebut yaitu adanya aksi nyata dalam pelayanan publik serta pertumbuhan ekonomi yang cukup baik yang berdampak positif dalam daya saing nasional Indonesia. Namun dalam pilar peningkatan nilai Reformasi Birokrasi masih perlu kerja keras dan aksi nyata pemerintah dalam mewujudkannya.

Gambar 1. Perkembangan Peringkat Government Effectiveness Negara-negara di Asia (per Tahun)

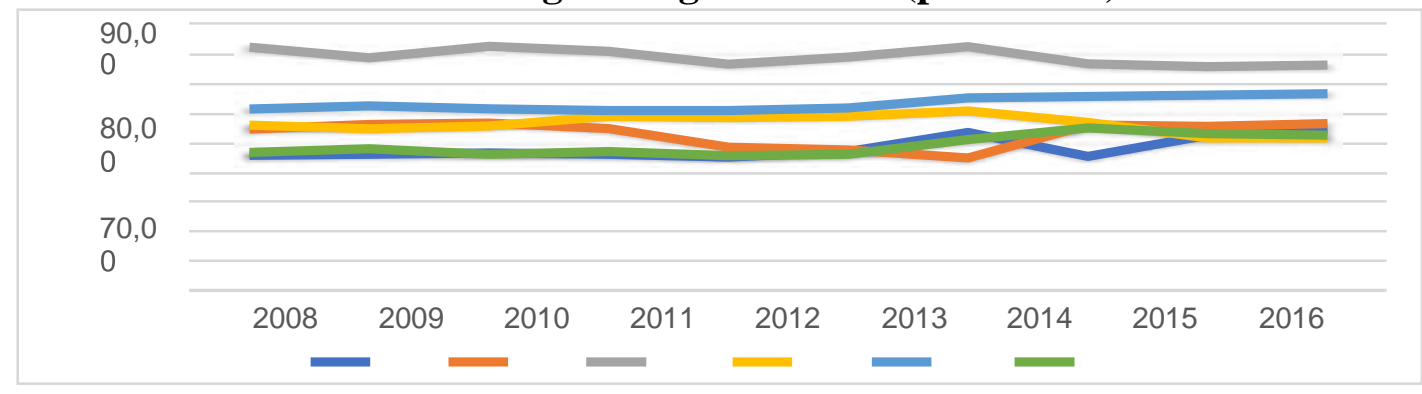

Sumber : World Bank (2018) 
Pada tahun 2008 hingga 2017 data berdasarkan indikator terpilih dalam penilaian tata kelola pemerintah yang dilakukan oleh world bank menunjukkan bahwa Indonesia terus mengalami peningkatan yang cukup baik pada efektifitas tata kelola pemerintah di Indonesia. pada tahun 2012 Indonesia mencapai persentase ranking sebesar 45.50 dari 100 (rank tertinggi) sedangkan pada tahun 2016 mengalami peningkatan hingga 52.88 dari 100 (rank tertinggi) (databank.worldbank.org). Tetapi data tersebut masih kurang memuaskan jika dibandingkan dengan pengimplementasian reformasi sistem penganggaran menjadi penganggaran berbasis kinerja yang telah dilakukan pengadopsian sejak tahun 2010. Data tersebut masih belum menunjukkan peningkatan yang cukup signifikan dalam pencapaian pemerintahan yang efektif sejak diterapkannya sistem pengelolaan anggaran publik berbasis kinerja serta pencapaian nilai Reformasi Birokrasi. Jika dibandingkan dengan negara-negara Asia lainnya Indonesia cukup mampu bersaing dalam peningkatan pemerintahan yang efektif namun jika dibandingkan dengan negara tetangga kita yaitu Malaysia maka Indonesia kalah telak dikarenakan data menunjukkan bahwa Malaysia mampu mengungguli negara-negara tetangganya dalam efektifitas pemerintahannya. Maka dari itu perlu adanya pengkajian mendalam pada hubungan antara penerapan penganggaran berbasis kinerja dan pencapaian Reformasi Birokrasi dengan terwujudnya pemerintahan yang efektif dikarenakan munculnya fenomena apakah memang pengelolaan pemerintah di Indonesia sudah optimal atau perlu dilakukan pengadopsian sistem lainnya untuk menata pemerintahan Indonesia agar menjadi lebih baik lagi.

Banyak studi telah dilakukan terkait sistem pengelolaan anggaran dengan metode PBK ini di Indonesia. Namun beberapa penelitian hanya terfokus pada implementasi penerapan sistem penganggarannya saja. Studi uang dilakukan sebelumnya banyak terfokus pada penerapan penganggaran berbasis kinerja terhadap akuntabilitasnya dari perspektif value for money (Kurrohman, 2013). Adapula penelitian sebelumnya menemukan hubungan penerapan penganggaran berbasis kinerja terhadap pengukuran kinerja pegawai yang dilakukan pada kasus pemerintahan daerah (Sofyani, 2018). Sementara itu, penelitian penganggaran berbasis kinerja berhubungan dengan pemerintahan yang efektif belum pernah ada dan belum pernah pula dilakukan oleh para peneliti di Indonesia. Maka dari itu sebuah tantangan besar yang ingin diperoleh oleh penulis dengan melakukan penelitian ini.

Selain itu, semua penelitian sebelumnya menggunakan pendekatan metode kualitatif dengan penelitian tunggal/ survei. Hasil data yang diperoleh oleh peneliti sebelumnya dapat dianggap hanya sebagai hasil data sebuah prasangka. Oleh karena itu, pada penelitian kali ini penulis akan menggunakan data kuantitatif dengan metode pengujian regresi linear sederhana/ ordinary least square (Gujarati, 2009) dengan menggunakan sampel data panel 70 kementerian/ lembaga pada pemerintah pusat dalam kurun waktu 2014-2018 untukmendapatkan data yang lebih akurat dan dapat terukur.

Objek penelitian ini adalah Kementerian dan Lembaga yang berada di bawah Pemerintahan Indonesia. Tidak ada pengklasifikasian kategori dalam objek penelitian dikarenakan hampir semua Kementerian dan Lembaga digunakan dalam pengukurannya. Dengan latar belakang tersebut, maka penelitian ini akan meneliti pengaruh dari penganggaran berbasis kinerja terhadap reformasi birokrasi di Indonesia. 


\section{Metode Penelitian}

Penelitian ini menggunakan data capaian Reformasi Birokrasi (RB) Kementerian dan Lembaga menggunakan pendekatan indeks Reformasi Birokrasi yang berasal dari penilaian Kemenpan RB dari tahun 2014 sampai 2018. Diketahui pula dalam penelitian ini yang menjadi variabel utama adalah variabel Penganggaran Berbasis Kinerja (PBK) yang diperolehdari data Sistem Monitoring dan Evaluasi Kinerja Terpadu (SMART), Kementerian Keuangan(PMK, 2011). Sedangkan variabel kontrol penelitian ini antara lain: pagu anggaran /alokasi anggaran pada Kementerian dan Lembaga dan jumlah Aparatur Sipil Negara (ASN). Data yang digunakan dalam penelitian ini adalah data panel yang terdiri dari seluruh Kementerian dan Lembaga di bawah naungan Pemerintah Pusat.

Data-data tersebut adalah data sekunder yang dikumpulkan dari aplikasi SMART Kemenkeu dan Laporan Keuangan Pemerintah Pusat (LKPP). Pengolahan data dilakukan dengan menggunakan pendekatan ekonometrika yaitu Ordinary Least Square yang dimana metode tersebut untuk meneliti pengaruh dari variabel independen kepada variabel dependen. Variabel dependen yang digunakan indeks Reformasi Birokrasi (RB), Kemenpan RB, hal ini merupakan capaian RB pada setiap Kementerian dan Lembaga. Berikut persamaan yang digunakan dalam penelitian ini yang dimana persamaan yaitu:

$$
\begin{array}{ll}
R B \text { it }= & \beta \mathrm{O}+\beta 1 P A \text { it }+\beta 2 P \text { it }+\beta 3 P K \text { it }+\beta 4 E \text { it }-1+\beta 5 A S N \text { it }+ \text { eit } \\
\mathrm{RB}= & \text { Indeks capaian kinerja birokrasi kementerian dan lembaga (skala likert 1-10) } \\
\mathrm{PA}= & \text { Pagu anggaran pada kementerian dan lembaga (dalam rupiah) } \\
\mathrm{P} & =\text { Penyerapan anggaran pada kementerian dan lembaga (skala likert 1-100) } \\
\mathrm{PK}= & \text { Capaian keluaran/output pada kementerian dan lembaga (skala likert 1-125) } \\
\mathrm{E}= & \text { Lag dari Efisiensi penggunaan anggaran kementerian dan lembaga } \\
& \text { (skala likert 1-20) } \\
\mathrm{ASN}= & \text { Jumlah Aparatur Sipil Negara } \\
\varepsilon & =\text { Error term } \\
\text { it } & =\text { gabungan cross section dan time series data }
\end{array}
$$

\section{Hasil dan Pembahasan}

Tabel 1. Hasil Olah Penelitian

\begin{tabular}{|c|c|c|}
\hline Variabel & Koefisien & T-Statistik \\
\hline $\mathrm{C}$ & $2,780389^{* * *}(0,0000)$ & 7.581241 \\
\hline Pagu Anggaran & $0,212363^{* * *}(0.0646)$ & 1.857700 \\
\hline Penyerapan Anggaran & $0.072090^{* * *}(0,0000)$ & 5.267445 \\
\hline Pencapaian Keluaran & $0.003333^{* *}(0.1111)$ & 1.599999 \\
\hline Efisiensi & $0.058104 * * *(0,0000)$ & 8.350786 \\
\hline $\begin{array}{c}\text { Aumlah } \\
\text { Negara }\end{array}$ & $-0.000433^{* * *}(0.0328)$ & -2.148758 \\
\hline Prob (F-Statistic) & $0,000000^{* * *}$ & \\
\hline Adj R-Squared & 0.980705 & \\
\hline
\end{tabular}


Penerapan Penganggaran Berbasis Kinerja Dan Reformasi Birokrasi Di Indonesia

Dalam segmen ini akan dibahas bagaimana penganggaran berbasis kinerja dapat memengaruhi capaian Reformasi Birokrasi (RB) pada Kementerian Negara dan Lembaga. Jika penganggaran berbasis kinerja dihitung secara keseluruhan, seperti dengan penelitian sebelumnya yang dijadikan referensi dalam penelitian ini yaitu penganggaran berbasis kinerja memiliki hubungan positif terhadap kinerja organisasi. Jika dianalisis berdasarkan indikator pengukuran penganggaran berbasis kinerja. Terdapat 3 (tiga) indikator yang digunakan dalam penelitian ini dan memiliki peran masing-masing untuk meningkatkan reformasi birokrasi, variabel pengukuran tersebut terpilih berdasarkan teori yang dikemukakan oleh (Habiburrochman, 2012) bahwasannya penganggaran berbasis kinerja diukur melalui input, output serta outcome yang dicapai oleh kementerian dan lembaga. Pada penelitian ini difokuskan terhadap variabel penyerapan anggaran, capaian keluaran, serta efisiensi.

Penyerapan anggaran merupakan variabel yang mewakili efisiensi dan efektifitas suatu lembaga dalam mengalokasikan anggaran. Penyerapan juga dikaitkan oleh para ahli dalam tiga karakteristik utama yaitu kapasitas keuangan yang merupakan kemampuan suatu lembaga untuk membiayai kegiatan dan proyek yang didukung oleh pemerintah, kapasitas ekonomi makro serta kapasitas dalam administrasi seperti bagaimana menjual otoritas lokal dan pusat dapat mengawasi proyek dan kegiatan pemerintah (Gibson et al., 2013) Peningkatan dari penyerapan anggaran suatu lembaga akan meningkatkan implementasi dalam perencanaan anggaran yang telah disusun sebelumnya. Hal tersebut tentu saja akan berimplikasi terhadap target kinerja yang telah direncanakan. Pada akhirnya program pembangunan yang telah direncanakan akan lancar dan sesuai jadwal (Zaman \& Georgescu, 2009). Dengan adanya peningkatan penyerapan anggaran tersebut maka akan meningkatkan faktor-faktor yang diukur tersebut dan hal ini dapat meningkatkan efisiensi dalam mencapai target kinerja organisasi. Penyerapan anggaran dapat meningkatkan output penganggaran berbasis kinerja yaitu pencapaian sasaran strategis pada kementerian dan lembaga (Juanda \& Kemenkeu, 2003).

Capaian keluaran atau kita mengenal dengan sebutan capaian output sangat erat kaitannya dengan kinerja organisasi. Setiap organisasi pasti memiliki tujuan dan target yang akan dicapai oleh lembaganya. Tercapaianya output dalam sebuah organisasi merupakansebuah cerminan dalam kinerja yang telah dicapai dalam sebuah organisasi. Menurut Pasolong, 2010 beliau mengemukakan bahwa salah satu faktor yang mempengaruhi kinerja organisasi adalah faktor penetapan tujuan yang jelas, kejelasan penetapan tujuan merupakan faktor penentu dalam pencapaian kinerja agar tercapainya tujuan dengan efektif dan efisien. Peningkatan capaian keluaran/ output dari capaian tujuan organisasi ini berdampak kepada capaian sasaran organisasi yang efektif dan efisien. Menurut (Mahsun, 2006) terdapat elemen pengukuran kinerja organisasi yaitu: 1) menetapkan tujuan, sasaran dan strategi organisasi; 2) merumuskan indikator dan ukuran kinerja; 3) mengukur tingkat ketercapaian tujuan dan sasaran-sasaran organisasi. Dalam hasil penelitian ini variabel capaian keluaran/output menunjukkan signifikan dan mempunyai korelasi positif terhadap reformasi birokrasi. Peningkatan capaian keluaran/output maka akan meningkatkan capaian dari reformasi birokrasi pada kementerian dan lembaga.

Efisiensi merupakan indikator ketiga dari penganggaran berbasis kinerja yang dapat ditingkatkan, efisiensi ini diukur melalui pengukuran efisiensi penggunaan anggaran yang telah ditetapkan dalam pedoman pengukuran evaluasi kinerja (PMK, 2011). Efisiensi 
penggunaan anggaran ini membandingkan antara pengukuran target volume keluaran dengan realisasi anggaran pada setiap kementerian dan lembaga. Ketika efisiensi suatu lembaga ini semakin baik maka akan meningkatkan birokrasi yang baik dalam suatu lembaga sehingga berimplikasi peningkatan kinerja organisasi. Hal tersebut sangat mendukung penelitian ini, penelitian ini menemukan bahwa efisiensi memiliki pengaruh positif terhadap birokrasi. Menurut pendapat yang berasal dari (Mardiasmo, 2006) bahwa efisiensi mempunyai hubungan erat terhadap konsep produktifitas. Pengukuran dari efisiensi itu sendiri dilakukan dengan menggunakan perbandingan antara ouput yang dihasilkan dan input yang telah digunakan (cost of output). Sebuh proses kegiatan dikatakan telah efisien jika pada suatu produk atau hasil kerja tertentu dapat dicapai dengan menggunakan sumber daya yang seminimal mungkin (spending well). Indikator efisiensi menggambarkan hubungan antara input sumber daya yang digunakan oleh unit organisasi (seperti: staf, upah, biaya administratif) dan keluaran yang telah dihasilkan. Hasil penelitian mengungkapkan bahwa benar adanya konsep yang dikemukakan oleh (Mardiasmo, 2006) tersebut bahwa dengan peningkatan efisiensi maka akan terjadi peningkatan kinerja organisasi. Hal tersebut dijelaskan pada teori efisiensi yang dikemukakan oleh (Mardiasmo, 2006) bahwa efisiensi merupakan rasio perbandingan output dan input. Semakin tinggi output yang dihasilkan dibandingkan input maka akan tercipta efisiensi. Dalam hal ini output yang dimaksud adalah output yang dicapai oleh Kementerian dan Lembaga yang yang berimplikasi pada peningkatan nilai Reformasi Birokrasi pada Kementerian dan Lembaga Pemerintah Pusat.

Penggunaan variabel kontrol memang dianggap konstan, karena untuk penelitian tidak bisa hanya variabel utama yang digunakan, akan tetapi dalam penelitian ini akan dijelaskan pengaruh dari penggunaan variabel utama tersebut. 2 (dua) variabel kontrol yang digunakan, diketahui kedua variabel tersebut memiliki pengaruh yang terdiri dari pagu anggaran dan jumlah ASN pada kementerian dan lembaga.

Pagu anggaran atau lebih kita kenal dengan sebutan alokasi anggaran memiliki hasil yang sejalan dengan teori yang digunakan pada tinjauan pustaka, yang dimana pagu anggaran memiliki pengaruh positif terhadap reformasi birokrasi yang dapat berpengaruh terhadap birokrasi pada suatu lembaga. untuk menjelaskan pengaruh pagu anggaran ini, dapat dijelaskan melalui teori niskanen (Niskanen, 1971). Teori ini menggambarkan bahwa birokrasi cenderung memperbesar anggaran. Penemuan dalam penelitian ini sejalan dengan teori yang dikemukakan oleh William Niskanen pada bukunya Representatif Government. Niskanen mengatakan bahwa pemaksimalan anggaran bertindak sebagai perwakilan utilitas birokrat. Dengan kata lain kenaikan pagu anggaran akan berdampak pada peningkatan birokrasi pada suatu lembaga dikarenakan seorang birokrat akan cenderung memilih untuk berusaha memaksimalkan anggaran untuk mencapai pemaksimalan utilitasnya.

\section{Kesimpulan}

Variabel dependen dari penelitian ini berupa Reformasi Birokrasi (RB) yang menggambarkan pengukuran kinerja organisasi pada kementerian dan lembaga, dan pengukuran reformasi birokrasi disajikan dalam bentuk indeks Reformasi Birokrasi. Variabel independen yang digunakan dalam penelitian ini adalah Penganggaran Berbasis Kinerja (PBK), diwakili oleh indikator Penyerapan Anggaran (P), Pencapaian Keluaran (PK) dan 
Penerapan Penganggaran Berbasis Kinerja Dan Reformasi Birokrasi Di Indonesia

Efisiensi (E) yang menjadi fokus penelitian dan menggunakan 2 variabel kontrol yang terdiri dari Pagu Anggaran/ Alokasi Anggaran dan Jumlah Aparatur Sipil Negara (ASN).

1. Penyerapan anggaran memiliki pengaruh positif terhadap variabel Reformasi Birokrasi. Penyerapan anggaran merupakan variabel yang mewakili efisiensi dan efektifitas suatu lembaga dalam mengalokasikan anggaran. Peningkatan dari penyerapan anggaran suatu lembaga akan meningkatkan implementasi dalam perencanaan anggaran yang telah disusun sebelumnya. Hal tersebut tentu saja akan berimplikasi terhadap target kinerja yang telah direncanakan. Dengan adanya peningkatan penyerapan anggaran tersebut maka akan meningkatkan efisiensi dalam mencapai target kinerja organisasi yang berimplikasi pada peningkatan reformasi birokrasi.

2. Pencapaian keluaran memiliki pengaruh yang signifikan terhadap variabel dependen yaitu Reformasi Birokrasi. Peningkatan capaian keluaran/output dari capaian tujuan organisasi ini berdampak kepada capaian sasaran organisasi yang efektif dan efisien. Sehingga peningkatan capaian keluaran/output maka akan meningkatkan capaian dari reformasi birokrasi pada kementerian dan lembaga.

3. Efisiensi memiliki pengaruh yang signifikan terhadap Reformasi Birokrasi. Tetapi pada penelitian ini menemukan bahwa efisiensi memiliki pengaruh positif terhadap birokrasi, hal tersebut sesuai dengan hipotesis yang ada. Hal tersebut mendukung teori yang dikemukakan oleh (Mardiasmo, 2006) bahwa efisiensi berkaitan erat dengan output dan input. Semakin besar rasio output yang dihasilkan dibandingkan input maka akan terciptanya efisiensi yang beimplikasi pada kinerja organisasi.

4. Pagu anggaran memiliki pengaruh positif terhadap reformasi birokrasi yang dapat berpengaruh terhadap birokrasi pada suatu lembaga. Niskanen mengatakan bahwa pemaksimalan anggaran bertindak sebagai perwakilan utilitas birokrat. Dengan kata lain kenaikan pagu anggaran akan berdampak pada peningkatan birokrasi pada suatu lembaga dikarenakan seorang birokrat akan cenderung memilih untuk berusaha memaksimalkan anggaran untuk mencapai pemaksimalan utilitasnya.

5. Jumlah Aparatur Sipil Negara (ASN) memiliki pengaruh negatif terhadap reformasi birokrasi. Menurut Niskanen para birokrat rasional akan bertindak dan berusaha untuk meningkatkan kepentingan publik. Para birokrat saat ini sudah mulai memiliki kesadaran dalam bertindak sesuai dengan peraturan yang berlaku tanpa memikirkan peningkatan kepentingan pribadinya. Dengan adanya penurunan penerimaan pegawai negeri sipil maka para aparatur yang dipekerjakan dalam pemerintahan akan lebih spesifik sesuai dengan bidang pekerjaan yang akan diambilnya. 


\section{Bibliografi}

Gibson, B., Hassan, S., \& Tansey, J. (2013). Sustainability assessment: criteria and processes. Routledge.

Gujarati, D. N. (2009). Basic econometrics. Tata McGraw-Hill Education.

Habiburrochman, \& A. R. (2012). Effect of Performance-Based Budgeting to Effectiveness of Control: (A Study Case at Indonesia's State University). Paper read at World Business Research Conference.

Indonesia, Pemerintah Republik. (2003). Undang-Undang Republik Indonesia Nomor 17 Tahun 2003 tentang Keuangan Negara.

Indonesia, Presiden Republik. (n.d.). Peraturan Presiden Republik IndonesiaNomor 81 Tahun 2010 Tentang Grand Design Reformasi Birokrasi2010-2025.

Juanda, B., \& Kemenkeu, A. T. (2003). Metode Statistik. Departemen Statistika Institut Pertanian Bogor, Bogor.

Kurrohman, T. (2013). Evaluasi penganggaran berbasis kinerja melalui kinerja keuangan yang berbasis value for money di kabupaten/kota di Jawa Timur. Jurnal Dinamika Akuntansi, $5(1)$.

Locke, E. A., \& Bryan, J. F. (1969). The directing function of goals in task performance. Organizational Behavior and Human Performance, 4(1), 35-42.

Mahsun, M. (2006). Pengukuran Kinerja Sektor Publik: Cetakan Pertama. Yogyakarta: Penerbit BPFE-Yogyakarta.

Mardiasmo, M. (2006). Perwujudan transparansi dan akuntabilitas publik melalui akuntansi sektor publik: suatu sarana good governance. Jurnal Akuntansi Pemerintah, 2(1).

Niskanen, W. A. (1971). Bureaucracy and Representative Government. Transaction Publishers.

PMK, 249 tahun 2011. (2011). Peraturan Menteri Keuangan Nomor 249/PMK. 02 Tahun 2011 tentang Pengukuran dan Evaluasi Kinerja atas Pelaksanaan Rencana Kerja dan Anggaran Kementerian Negara/Lembaga. Lembaga. Jakarta.

Sofyani, H. (2018). Does performance-based budgeting have a correlation with performance measurement system? Evidence from local government in Indonesia. Foundations of Management, 10(1), 163-176.

Taufiq, M. et all. (2014). Kajian Model Reformasi Birokrasi. Pusat Kajian Reformasi Administrasi Lembaga Administrasi Negara. Pusat KRA-LAN.

Zaman, G., \& Georgescu, G. (2009). Structural fund absorption: A new challenge for Romania? Romanian Journal of Economic Forecasting, 1(2009), 136-154. 